\title{
Study on Behaviour of Stud Type Shear Connector in Composite Beam Using ANSYS
}

\author{
T.Subramani $^{1 *}$, A.Periasamy ${ }^{2}$ \\ 1*Managing Director, Priyanka Associates (Civil Engineers and Valuers), Salem, TamilNadu, India. \\ ${ }^{2}$ Proprietor, Harisudhan Promotors, Trichy, TamilNadu, India. \\ "Corresponding author E-mail: tsmcivil2007@gmail.com
}

\begin{abstract}
Composite plays a vital role in replacing the existing mild steel in reinforcement and exterior truss structure. This study proposed to design shear connector for joining concrete slab and steel section. Shear connectors has analyzed and predict the best connector for a particular composite beam with respect to static load and the amount of steel in the connector as a common aspect. The use of composite structures is increasingly present in civil construction works nowadays. Composite beams, especially, are structures which include substances, a metal phase placed in particular inside the tension region and a concrete phase, positioned in the compression go sectional location, both are related with the aid of steel gadgets called shear connectors. The main features of this connector are to permit the weight for the joint the beam-column, to restriction longitudinal slipping and uplifting on the factors interface the shear forces. Our project paper presents 3D numerical models of steel-concrete composite beams to simulate their structural behaviour, with emphasis on the beam column interface using Simulations software ANSYS 18.1 based on the Finite Element Method. Mostly these type of structures are widely used in the dynamic loading structures like bridges and high rise buildings.
\end{abstract}

Keywords: Behaviour, stud, shear connector, composite Beam, ANSYS.

\section{Introduction}

Composite material is one in which the combination of one or more material reinforced, plated and mixed while concreting. This material withstand the more load compared to mild steel structure. This plays partial role in choosing title as composite connector which connect the structural members in joints of the concrete. Composite Construction will have the advantages of both prefabricated and cast-in situ construction. Stabilize girders during transportation and construction

- Do not require stiffeners because of high centre of gravity

- Avoid the use of braces for concreting of residual in-situ plates

- Make the task of scaffolding of concrete plated un-required.

\subsection{Shear Connectors}

Mostly in construction three composite materials are used

- Reinforced concrete slab

- Steel beam

- Shear connector

In this, shear connector is one which plays vital role in the load bearing member is basically used to tie the concrete slab to the steel beam in order to transfer the horizontal shear between the slab and the beam without slip and at the same time to prevent the vertical separation of the slab from the structural steel member at the inner face.

\section{Methodology}

Fig. 1 shows the methodology of the study.

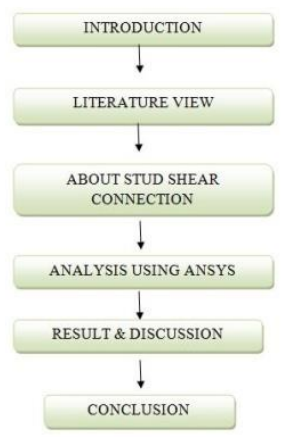

Fig.1: Methodology

\section{About the Software}

Analytical software plays vital role in numerical study and stimulation. Which intend in study the load bearing structure with respect to dynamic and static load condition under different basement like concrete and composite etc., ANSYS is general purpose software used to simulate all structural members with respect to static and dynamic analysis. In this software modelling and analytical work has been generated with graphical representation. In this the original body or the structure is then considered as an assemblage of these elements connected at a 
finite number of joints called Nodes or Nodal Points. The properties of the elements are formulated and combined to obtain the solution for the entire body or structure. ANSYS can import all kinds of CAD geometries (3D and 2D) from different CAD software's and perform simulations, and also it has the capability of creating one effortlessly. ANSYS has inbuilt CAD developing software's like Design Modeller and Space Claim which makes the work flow even smoother.

\section{Shear Connector in Composite Beam}

\subsection{Shear Connectors}

In construction of buildings and bridges, shear connectors are used as a latest technology. Shear connectors are used as a important and major element in the composite structure. It is gaining popularity in the construction industry because of durability, high load bearing capacity, excellent quality, faster speed of construction, etc. are some of the reasons. "Shear connector means headed steel studs. These are welded to a structural member for achieving composite action with concrete. Shear connector is one of the major elements in the composite structure.

\subsection{Advantages of Shear Connector}

1. Shear Connectors have high load bearing capacity and offer heavy resistance for failure by shearing, in composite structure.

2. Very high rate of production can be achieved, during construction.

3. Ease of operation, during construction. No specific skill is required for welding.

4. Flexibility in design of construction.

5. Shear Connectors can be welded through Deck Sheet, to produce concrete slab.

6. Size of columns are smaller hence for given built up area we can have larger carpet area

7. Strong, durable, stable and seismic resistant.

\subsection{Requirements of Shear Connectors}

1. The minimum distance between the edge of a shear connector and the edge of a flange plate is $25 \mathrm{~mm}$

2. The maximum longitudinal spacing is defined, and is the lower of $800 \mathrm{~mm}$ or $4 \mathrm{x}$ concrete slab thickness

3. If the plate is subjected to tensile stress or fatigue loading, diameter of the shear stud should not exceed one and a half times the plate thickness,

4. Diameter of the shear stud should not exceed 2.5 times the plate thickness in other cases.

5. Underside of the head of shear stud should project at least 30 $\mathrm{mm}$ above the bottom transverse reinforcement, thus it govern the height of the stud.

\subsection{Advantages of Shear Studs}

The advantages of shear studs over other forms of connectors are that the

1. Installation and welding process is quick and simple;

2. Provides little obstruction to the slab reinforcement;

3. Allows more satisfactory compaction of the concrete around the connectors;

4. It provides equal shear strength in all directions. The advantages of headed stud connectors can be summarized as follows: fast welding, good anchor in concrete, the arrangement of reinforcement through the slab is easy, production of large scale size is easy, the standard dimensioned head is a resistance factor for slab uplift and they are practical for use in steel deck slabs. Four portions that are considered for load bearing of studs as suggested by include the concrete behind the weld collar, bending and shearing load-bearing capacity in the lower area of the connector shaft, tensile force in the connector shaft and the friction forces in the composite interface. There are almost no tensile forces acting on the shank in high strength concrete

\subsection{Role of Shear Connector in Composite Structure}

1. A Shear connector belongs to a steel projection to be applied on the top flange of steel composite bridge girders to transmit required shear among the steel girder and composite slab to facilitate composite action.

2. The headed stud is mostly recognized form of shear connector, or shear stud. Other forms of shear connector range from block and hoop, and channel connectors. Block and hoop, and channel connectors are mainly applied for transmission of large shear. These are good substitute to narrowly spaced shear studs.

3. Shear flows are measured at supports, at mid-span, and at quarter points, with the intension of planning a shear flow profile along a girder. Shear Connectors or studs are placed to withstand shear at the relevant locations.

4. Standard sizes for shear studs, which are generally utilized in steel composite bridge decks and quickly obtainable from suppliers, are of heights (in mm) 125, 150, 175, 200, 250 and diameters (in mm) 161922 25. Normally, a welding gun is used to connect the shear studs to the top flanges of girders. The stud is kept in the welding gun and an arc is attached between stud and the flange plate. Arc combines a section of both the stud and the plate in a pre-arranged time.

\subsection{Benefits of Shear Studs}

The following are the benefits of shear studs over other forms of connectors.

1. Set up and welding method is easy and quick.

2. Offers least obstacle to the slab reinforcement.

3. Facilitates more reasonable compaction of the concrete all over the connectors.

4. Offers identical shear strength in all directions Prerequisites of Shear Connectors.

5. The lowest distance among the edge of a shear connector and the edge of a flange plate should be $25 \mathrm{~mm}$.

6. When the plate is dependent on tensile stress or fatigue loading, diameter of the shear stud must not surpass one and a half times the plate thickness.

7. Diameter of the shear stud must not surpass 2.5 times the plate thickness in other cases.

8. Foundation of the head of shear stud should be minimum 30 $\mathrm{mm}$ above the bottom transverse reinforcement, so that it manages the height of the stud.

\section{Result and Discussion}

\subsection{Total Deformation at Pin Distance $=60 \mathrm{~mm}$ and Pin No $=9$}

Table 1 shows the Load V/s Deformation

Table 1: Load V/s Deformation

\begin{tabular}{|c|c|}
\hline LOAD (KN) & DEFORMATION(MM) \\
\hline 100 & 53.08 \\
200 & 106.39 \\
300 & 159.91 \\
400 & 213.59 \\
500 & 267.42 \\
600 & 321.38 \\
700 & 375.73 \\
800 & 432.88 \\
900 & 496.93 \\
1000 & 588.93 \\
\hline
\end{tabular}


Fig. 2 shows the deformation.

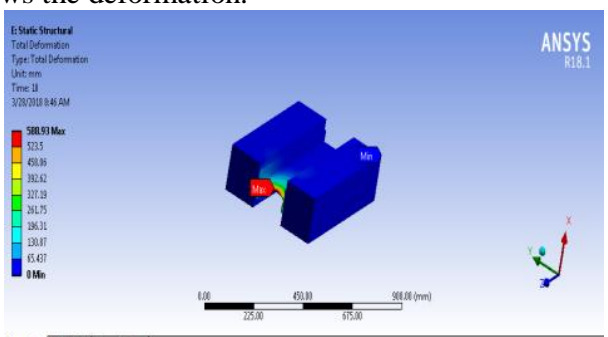

Fig 2: Deformation

Fig. 3 shows the graph of deformation

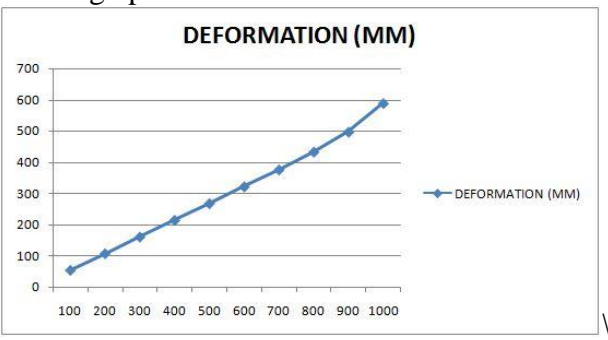

Fig.3: Deformation in graph

\subsection{Total Deformation at Pin Distance $=75 \mathrm{Mm}$ and Pin} No $=7$

Table 2 shows the Load V/s Deformation

Table 2: Load V/s Deformation

\begin{tabular}{|c|c|} 
Table 2: Load V/s Deformation \\
\hline LOAD(KN) & DEFORMATION(MM) \\
\hline 100 & 53.106 \\
200 & 106.47 \\
300 & 160.04 \\
400 & 213.77 \\
500 & 267.64 \\
600 & 321.62 \\
700 & 375.8 \\
800 & 432.57 \\
900 & 498.62 \\
1000 & 592.47 \\
\hline
\end{tabular}

Fig. 4 shows the deformation.

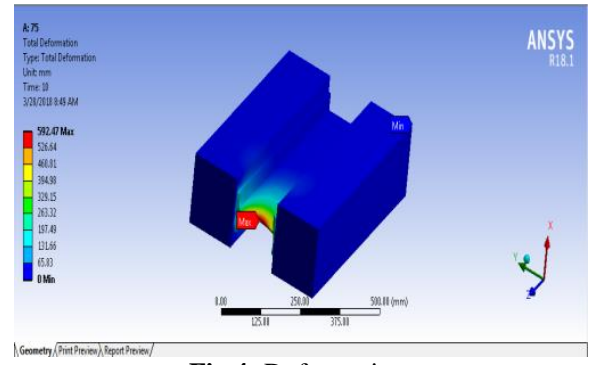

Fig 4: Deformation

Fig. 5 shows the graph of deformation

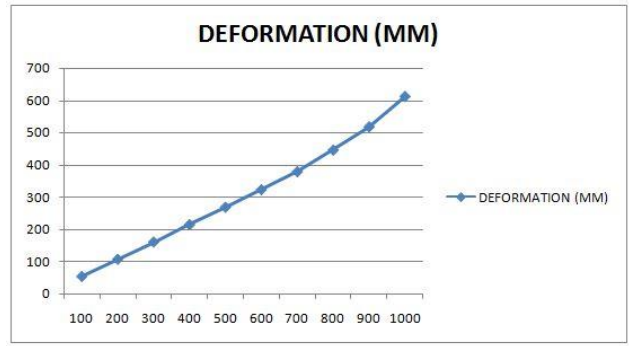

Fig.5: Deformation in graph

\subsection{Total Deformation at Pin Distance $=90 \mathrm{Mm}$ and Pin No $=6$}

Table 3 shows the Load V/s Deformation
Table 3: Load V/s Deformation

\begin{tabular}{|c|c|}
\hline LOAD(KN) & DEFORMATION(MM) \\
\hline 100 & 53.221 \\
200 & 106.68 \\
300 & 160.34 \\
400 & 214.16 \\
500 & 268.13 \\
600 & 322.38 \\
700 & 378.14 \\
800 & 445.28 \\
900 & 517.41 \\
1000 & 611.65 \\
\hline
\end{tabular}

Fig.6 shows the deformation.

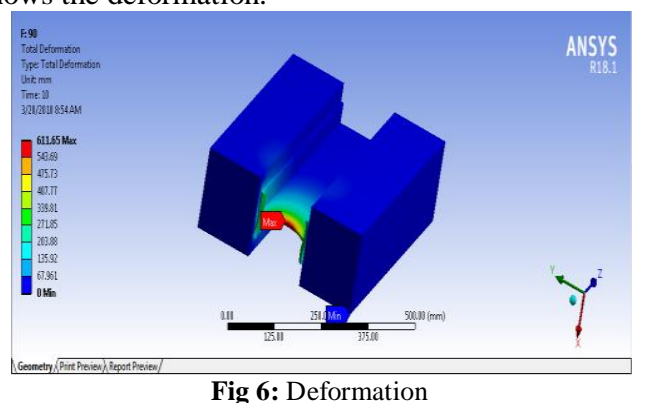

Fig.7 shows the graph of deformation

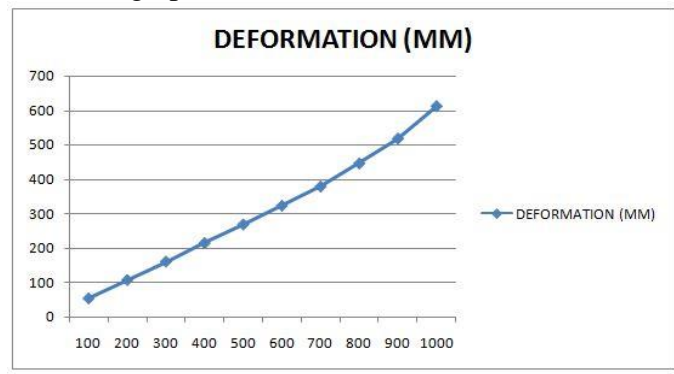

Fig.7: Deformation in graph

5.4. Total Deformation at Pin Distance $=105 \mathrm{~mm}$ and Pin No $=5$

Table 4 shows the Load V/s Deformation

Table 4: Load V/s Deformation

\begin{tabular}{|c|c|}
\hline LOAD $(\mathrm{KN})$ & DEFORMATION(MM) \\
\hline 100 & 53.479 \\
200 & 107.32 \\
300 & 161.47 \\
400 & 215.85 \\
500 & 270.42 \\
600 & 325.18 \\
700 & 383.02 \\
800 & 448.62 \\
900 & 521.04 \\
1000 & 605.34 \\
\hline
\end{tabular}

Fig. 8 shows the graph of deformation

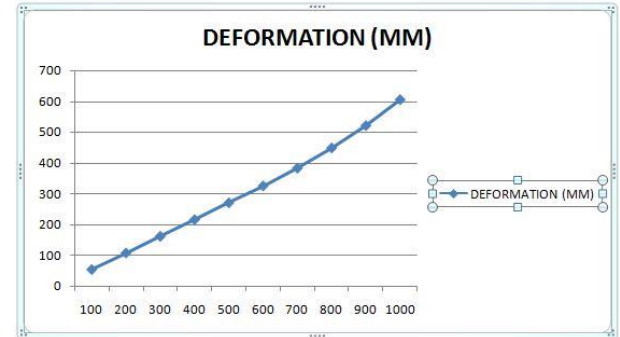

Fig.8: Deformation in graph

Fig.9 shows the deformation. 


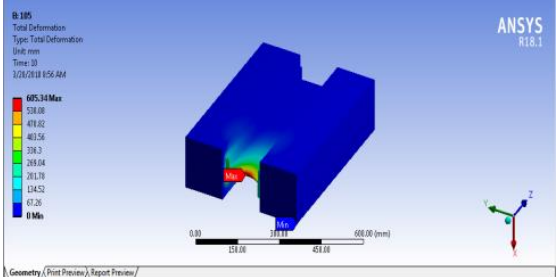

Fig 9: Deformation

Table 5 shows the comparison results of load V/s deformation

Table 5: Comparison results of load V/s deformation

\begin{tabular}{|c|c|c|c|}
\hline PIN NO & $\begin{array}{c}\text { PIN } \\
\text { DISTANCE(MM) }\end{array}$ & LOAD(KN) & DEFORMATION(MM) \\
\hline 9 & 60 & 1000 & 588.93 \\
\hline 7 & 75 & 1000 & 592.47 \\
\hline 6 & 90 & 1000 & 611.65 \\
\hline 5 & 105 & 1000 & 605.34 \\
\hline
\end{tabular}

Table 6 shows the material ratio and young's modulus

Table 6: Material ratio and young's modulus

\begin{tabular}{|c|c|c|}
\hline Material & ratio & $\begin{array}{c}\text { Young's modulus of } \\
\text { Elasticity(N/mm2) }\end{array}$ \\
\hline I beam & 0.3 & 200000 \\
\hline Shear connectors & 0.3 & 200000 \\
\hline
\end{tabular}

\section{Conclusion}

Through computations, it has been located that height of the shear connectors does now not impact tons the deflection of the composite beam. But, boom in diameter of the shear connectors decreases deflection in composite beam. In addition it's far found that shape of go phase of shear connector additionally topics in behavior of composite beam. The shear connectors having square move segment are discovered greater effective than people with round move phase for arresting the deflection of composite beam. a numerical research is achieved to examine the flexural behaviour of a steel concrete composite beam with stud shear connector and blind bolt shear connectors. Finite detail modeling and evaluation of the three dimensional models of the subassemblies have been executed within the program Ansys workbench 18.1. Based on the analysis results of the two models following conclusions were drawn:

1. An increase of $50 \%$ in the load carrying capacity of the composite beam was observed stud connection was used instead of the bolted connection.

2. The slippage is found to be $50 \%$ less in the subassembly model with welded connection when compared to that with bolted connection.

Thus, it was found that the subassembly model connection performed better bolted connection under flexural loading.

\section{References}

[1]. T.Subramani, J.Jayalakshmi , " Analytical Investigation Of Bonded Glass Fibre Reinforced Polymer Sheets With Reinforced Concrete Beam Using ANSYS", International Journal of Application or Innovation in Engineering \& Management (IJAIEM), Volume 4, Issue 5, pp. 105-112, 2015

[2]. T.Subramani. , S.Vishnupriya, "Finite Element Analysis of a Natural Fiber (Maize) Composite Beam", International Journal of Modern Engineering Research, Volume. 4, Issue. 6 (Version 1), pp $1-7,2014$,

[3]. T.Subramani., R.Senthil Kumar, "Modelling and Analysis of Hybrid Composite Joint Using Fem in ANSYS", International
Journal of Modern Engineering Research, Volume 4, Issue 6 (Version 1), pp 41- 46, 2014.

[4]. T.Subramani, S.Sharmila, "Prediction of Deflection and Stresses of Laminated Composite Plate with Artificial Neural Network Aid", International Journal of Modern Engineering Research, Volume 4, Issue 6 (Version 1), pp 51 -58, 2014.

[5]. T.Subramani., S.Sundar, M.Senthilkumar, "Investigation of the Behaviour for Reinforced Concrete Beam Using Non Linear Three Dimensional Finite Elements", International Journal of Modern Engineering Research, Volume. 4, Issue. 6 (Version 2), pp 13 -18, 2014 ,

[6]. T.Subramani, A.Arul, "Design And Analysis Of Hybrid Composite Lap Joint Using Fem" International Journal of Engineering Research and Applications, Volume. 4, Issue. 6 (Version 5), pp 289- 295, 2014.

[7]. T.Subramani., J.Jothi,, M.Kavitha "Earthquake Analysis Of Structure By Base Isolation Technique In SAP", International Journal of Engineering Research and Applications, Volume. 4, Issue. 6 (Version 5), pp 296 - 305, 2014.

[8]. T.Subramani., R.Manivannan.R, M.Kavitha, "Crack Identification In Reinforced Concrete Beams Using ANSYS Software" ,International Journal of Engineering Research and Applications, Volume. 4, Issue. 6 (Version 6), pp 133 - 141, 2014.

[9]. T.Subramani., Reni Kuruvilla, J.Jayalakshmi., "Nonlinear Analysis Of Reinforced Concrete Column With Fiber Reinforced Polymer Bars" International Journal of Engineering Research and Applications Volume. 4, Issue. 6 (Version 5), pp 306- 316, 2014.

[10]. T.Subramani, D.Sakthi Kumar, S.Badrinarayanan. "Fem Modelling And Analysis Of Reinforced Concrete Section With Light Weight Blocks Infill " International Journal of Engineering Research and Applications, Volume. 4, Issue. 6 (Version 6), pp 142 - 149, 2014.

[11]. T.Subramani, B.Saravanan., J.Jayalakshmi., "Dynamic Analysis Of Flanged Shear Wall Using Staad Pro", International Journal of Engineering Research and Applications, Volume. 4, Issue. 6 (Version 6), pp 150 - 155, 2014.

[12]. T.Subramani, M.Subramani., K.Prasath.,"Analysis Of Three Dimensional Horizontal Reinforced Concrete Curved Beam Using ANSYS" International Journal of Engineering Research and Applications, Volume. 4, Issue. 6 (Version 6), pp 156 - 161, 2014.

[13]. T.Subramani., K.Bharathi Devi., M.S.Saravanan. , Suboth Analysis Of RC Structures Subject To Vibration By Using ANSYS," International Journal of Engineering Research and Applications Vol. 4, Issue 12(Version 5), pp.45-54, 2014.

[14]. T.Subramani., K.Bharathi Devi., M.S.Saravanan., Suboth Thomas, "Analysis Of Seismic Performance Of Rock Block Structures With STAAD Pro International Journal of Engineering Research and Applications Vol. 4, Issue 12(Version 5), pp.55- 68, 2014.

[15].T.Subramani., T.Krishnan., M.S.Saravanan.M , Suboth Thomas, "Finite Element Modeling On Behaviour Of Reinforced Concrete Beam Column Joints Retrofitted With CFRP Sheets Using ANSYS" International Journal of Engineering Research and Applications Vol. 4, Issue 12(Version 5), pp.69 -76, 2014

[16]. T.Subramani., S.Krishnan., M.S.Saravanan.M, Suboth Thomas "Analysis Of Retrofitting Non-Linear Finite Element Of RCC Beam And Column Using ANSYS" International Journal of Engineering Research and Applications, Vol. 4, Issue 12(Version 5), pp.77-87, 2014.

[17]. T.Subramani, J.Jayalakshmi , " Analytical Investigation Of Bonded Glass Fibre Reinforced Polymer Sheets With Reinforced Concrete Beam Using ANSYS", International Journal of Application or Innovation in Engineering \& Management (IJAIEM), Volume 4, Issue 5, pp. 105-112, 2015

[18].T.Subramani and M.Kavitha, “Analysis Of Reliability Of Steel Frame Systems With Semi-Rigid Connections Using Numerical Method And Finite Element Analysis", International Journal of Applied Engineering Research (IJAER), Volume 10, Number 38, Special Issues, pp.28240$28246,2015$.

[19]. T.Subramani, M.S.Saravanan, "Analysis Of Non Linear Reinforced And Post Tensioned Concrete Beams Using ANSYS", International Journal of Applied Engineering Research (IJAER) International Journal of Applied Engineering Research (IJAER), Volume 10, Number 38 Special Issues, pp.28247-28252, 2015

[20]. T.Subramani, K.Balamurugan , " Finite Element Anaylsis Of Composite Element For FRP Reinforced Concrete Slab By Using ANSYS" , International Journal of Application or Innovation in 
Engineering \& Management (IJAIEM), Volume 5, Issue 5, pp. 076-084, 2016 .

[21]. T.Subramani, V.Kanian Poonkundran , " Prefabricated Multistory Structure Exposure To Engineering Seismicity By Using SAP", International Journal of Application or Innovation in Engineering \& Management (IJAIEM), Volume 5, Issue 5, pp. 123-131, 2016.

[22].T.Subramani, A.Kumaravel , " Analysis Of Polymer Fibre Reinforced Concrete Pavements By Using ANSYS" , International Journal of Application or Innovation in Engineering \& Management (IJAIEM), Volume 5, Issue 5, pp. 132-139, 2016

[23]. T.Subramani, R.Praburaj , " Pushover Anaylsis Of Retrofitted Reinforced Concrete Buildings By Using SAP" , International Journal of Application or Innovation in Engineering \& Management (IJAIEM), Volume 5, Issue 5, pp. 140-147, 2016.

[24]. T.Subramani, M.Senthilkumar , "Finite Element Anaylsis Of RC Beams With Externally Bonded Simcon Laminates By Using ANSYS" , International Journal of Application or Innovation in Engineering \& Management (IJAIEM), Volume 5, Issue 5, pp. $148-155,2016$

[25]. T.Subramani, R.Vasanthi , " Earth Quake Resistant Building Using SAP" , International Journal of Application or Innovation in Engineering \& Management (IJAIEM), Volume 5, Issue 5, pp. $173-181,2016$

[26]. T.Subramani, A.Selvam , " Studies On Economical Configuration Of RCC And Prestressed Shell Roofs By Using ANSYS ", International Journal of Application or Innovation in Engineering \& Management (IJAIEM), Volume 5, Issue 5, pp. 182-191, 2016.

[27]. T.Subramani, A.Anbuchezian , " Experimental Investigation On Flexural Behavior Of Folded Ferro Cement Panels ", International Journal of Application or Innovation in Engineering \& Management (IJAIEM), Volume 6, Issue 3, March 2017 , pp. $045-$ 049 , ISSN 2319 - 4847.

[28]. T.Subramani, A. Fizoor Rahman , " An Experimental Study On The Properties Of Pet Fibre Reinforced Concrete " , International Journal of Application or Innovation in Engineering \& Management (IJAIEM), Volume 6, Issue 3, March 2017 , pp. 058 066 , ISSN 2319 - 4847.

[29]. T.Subramani, S.Poongothai, S.Priyanka, " Analytical Study Of T Beam Column Joint Using FEM Software ", International Journal of Emerging Trends \& Technology in Computer Science (IJETTCS), Volume 6, Issue 3, May - June 2017 , pp. 148-156 , ISSN 2278-6856

[30]. T.Subramani, R.Ganapathy,V.Manoharan, M.Balamurugan, R.Murugesan, " Design And Analysis Of Light Weight Concrete Building Using ETAB With Respect To Dynamic Loading " , International Journal of Emerging Trends \& Technology in Computer Science (IJETTCS), Volume 6, Issue 3, May - June 2017 , pp. 252-258, ISSN 2278-6856.

[31]. T.Subramani, A.Mohammed Ali, R.Karthikeyan, E.Panner Selvan, K.Periyasamy , " Analytical Study Of T-Beam Using ANSYS ", International Journal of Emerging Trends \& Technology in Computer Science (IJETTCS), Volume 6, Issue 3, May - June 2017 , pp. 259-266 , ISSN 2278-6856.

[32]. T.Subramani, V.Kalaivanan, S.Priyaranjithkumar, P.Sasikumar, P.Vinoth Kumar, " Design And Analysis Of Multistorey Building With Respect To Seismic Loads Using ETABS " , International Journal of Emerging Trends \& Technology in Computer Science (IJETTCS), Volume 6, Issue 3, May - June 2017 , pp. 267-274 , ISSN 2278-6856. 